\title{
Identidade e diversidade religiosa no Brasil
}

\author{
Identity and religious diversity in Brazil
}

Identité et diversité religieuse en Brésil

Marcelo Tadvald ${ }^{1}$

Resumo: O Brasil tem por característica representar e ser representado como uma nação plural, inclusive no que diz respeito ao campo religioso. Entretanto, a partir de fontes e de referenciais bibliográficos e etnográficos, este texto propõe relativizar a ideia de pluralidade religiosa brasileira no sentido de mostrar a prevalência cristã na constituição da identidade nacional e a sua capacidade de atualização e de reprodutibilidade.

Palavras-chave: Brasil; pluralidade religiosa; identidade nacional; cristianismo.

Abstract: Brazil has a feature to represent and be represented as a plural nation, including its religious field. However, from different sources such as bibliographic and ethnographic references, this paper proposes to relativize the idea of Brazilian religious plurality in order to show the majority Christian in the national identity building and its ability to become in constant actualization.

Key-words: Brazil; religious plurality; national identity; christianity.

Résumé: Le Brésil se caractérise par être représentée comme une nation plurielle, y compris son champ religieux. Cependant, à partir de sources et des références bibliographiques et ethnographiques, cet article propose de relativiser l'idée de la pluralité religieuse brésilienne afin de montrer la prévalence chrétienne dans la formation de l'identité nationale et sa capacité de actualiser et de reproductibilité. Mots-clés: Brésil; la pluralité religieuse; l'identité nationale; christianisme.

${ }^{1}$ Doutor em Antropologia Social e pesquisador do CNPq e do Núcleo de Estudos da Religião da UFRGS, Brasil. E-mail: marcelotadvald@gmail.com

Latitude, Vol. 9, no 2, pp. 175-195, 2015

DOI: https://doi.org/10.28998/2179-5428.20150201 
Identidade e diversidade religiosa no Brasil

\title{
1. À título de introdução: notas sobre a pluralidade religiosa no Brasil
}

\author{
Se foi pra diferenciar \\ Que Deus criou a diferença \\ Que irá nos aproximar \\ Intuir o que Ele pensa \\ Se cada ser é só um \\ E cada um com sua crença \\ Tudo é raro, nada é comum \\ Diversidade é a sentença... \\ (Trecho de Diversidade - Lenine)
}

A ideia do Brasil se tratar de uma nação "plural" se tornou representação corrente devido ao seu peculiar processo histórico de miscigenação étnica e cultural, representação esta reforçada ao longo dos tempos por diferentes empreendimentos sociais e estatais. Tanto no Brasil quanto em outros países comparáveis a si em certos aspectos, tal pluralidade cultural é representada a partir de um mecanismo multicultural peculiar, que transforma cada uma das culturas em contato, apesar de manter as suas referências originais que permitem que essa pluralidade abranja parcelas da população maiores da que a de determinado grupo em particular. Se, por um lado, preserva-se assim a dimensão emblemática da cultura, permitindo a identificação entre diferentes segmentos sociais, por outro se perde, em grande medida, a ênfase no grupo étnico como parcela de nação, principalmente em se tratando de nações extensas demograficamente e/ou territorialmente (Tadvald, 2015).

A representação do país como "plural" atravessa diversas esferas da experiência brasileira. No quesito religioso, interpenetrações múltiplas, características desta sociedade, puderam abarcar o "outro" dentro da formação da nação, ao contrário da política identitária de outros países com tendência maior a processos de homogeneização de sua representação nacional. Portanto, no Brasil, o 
cenário foi mais favorável do que em outros lugares para o estabelecimento de um imaginário religioso mais amplo. Por exemplo, referenciais mediúnicos, como a possessão de espíritos, divindades, energias ou a adoção do primado da reencarnação (inclusive em setores do catolicismo popular), tornaram-se singulares, ecléticos ou sincretizantes de diversas religiosidades frutificadas em solo brasileiro (Velho, 1994).

A partir da difusão no imaginário nacional desta "lógica das possessões" (Segato, 2007), estabeleceu-se uma ética de acolhida da alteridade. No caso brasileiro, em sentido religioso, este "outro" pode ser percebido como as entidades e orixás dos terreiros afrorreligiosos, os espíritos do kardecismo, o animismo místico-esotérico, as entidades e deidades dos transes xamânicos e ayahuasqueiros, os demônios cristãos exorcizados ou mesmo o Espírito Santo entre alguns grupos pentecostais e neopentecostais, todos revelando esta metáfora da "coabitação" ou do "acolhimento e fusão com o outro" (Tadvald, 2007). Portanto, a ideia de participação da alteridade na construção identitária brasileira não soa de antemão invasiva ou inapropriada, quando, ao menos, analisamos o escopo religioso nacional, o que, a rigor, indica que as questões de alteridade estão sempre presentes no universo de construção de identidades em dado contexto social e cultural. Diria Stefania Capone que "no Brasil, os espíritos habitam os homens e habitam com os homens" (Capone, 1999, p. 34, tradução minha). Por aqui, também, devido a tal naturalização na possibilidade de participação da alteridade na construção da pessoa, facilita-se $o$ processo de intimidade nas relações sociais $e$, consequentemente, nas relações das pessoas com as instituições públicas e nos confusos limites que existem entre estes âmbitos. Dentre outros aspectos, tal ética de acolhida também facilita a consolidação de primados pluralizantes, ainda que alguns sejam bastante questionáveis.

Verifica-se, no Brasil, uma dificuldade histórica de consolidação de projetos políticos com tendências de homogeneização identitária diante de características culturais baseadas numa ética de acolhimento que, por si só, denota certa pluralidade. Soma-se a tais dificuldades de homogeneização identitária aspectos legados à pluralidade cultural do ethos indígena e africano e pelos demais fluxos imigratórios (europeus, asiáticos, latino-americanos, árabes), cada qual ao seu modo repositório legítimo do caráter e da identidade brasileira. 
Identidade e diversidade religiosa no Brasil

Tais âmbitos de significação contemplam no campo religioso nacional marcas de uma origem plural como traço de nossa identidade, representação que mascara a luta contra a prevalência histórica e socialmente enraizada do cristianismo que aqui chegou com o catolicismo colonial. Não foi pelo acaso, portanto, que certa confissão logrou se instituir no imaginário coletivo de um cenário social tão diversificado. Também não se resume aos inerentes conflitos, disputas, guerras ou coerção, mas por ter servido de não só de código, mas, sobretudo de linguagem no longo e inacabado processo de construção da identidade nacional brasileira que o catolicismo soube se impor como maior referente no Brasil (Costa, 1998).

Ainda que nos últimos anos o catolicismo oficial tenha perdido terreno para o crescente campo evangélico, o fato em si não ameaça a hegemonia do ethos cristão no país, mas, pelo contrário, pode atualizá-lo e contribuir para a sua manutenção e reprodução. Assim, se em termos da atual identidade religiosa nacional o primeiro aspecto que chama a atenção é a sua transformação promovida pelo recrudescimento da hegemonia católica de outrora (Sanchis, 1999), tal decréscimo não significa necessariamente a perda da hegemonia cristã na sociedade e no imaginário nacional.

O caráter encompassador do "típico" catolicismo brasileiro não tem por fim eliminar a pluralidade que lhe foi constituinte, mas, ao seu modo, absorvê-la em certos aspectos, como tem feito desde que por aqui chegou. E isto inclui desde feitiços e sortilégios das cosmologias afro-indígenas e campesinas transformados em simpatias e outros que tais pelo catolicismo popular até mesmo discursos revolucionários que deram vazão a algo como a Teologia da Libertação da segunda metade do século XX. Assim, este cristianismo "tipicamente brasileiro" estabeleceuse e contribuiu decisivamente para a prevalência de certas religiões nacionais, desde o catolicismo oficial até o fenômeno relativamente recente das igrejas neopentecostais (Tadvald, 2015).

Portanto, diante de um cenário plural, somado à maior individualização nas escolhas religiosas (Carvalho, 1999), algo característico da modernidade, e ainda que no Brasil sejamos capazes de construir nossas identidades religiosas a partir de múltiplas referências, mantém-se subjetivamente um referencial cristão de significação. Essa prevalência decorre de diferentes fatores, dentre os quais 
apresentarei a seguir alguns de natureza histórica para depois contrastar esse processo com os dados atuais a respeito do campo religioso nacional.

\section{Dados históricos constituintes da prevalência cristã na identidade nacional}

O catolicismo esteve presente na América Latina desde a chegada dos primeiros colonizadores ibéricos na região, tendo se estabelecido como a confissão dominante na formação dos subsequentes Estados nacionais durante todo o período colonial. No geral, durante a primeira metade do século XIX, e no Brasil, desde a independência em 1822, a Igreja Católica ainda organizava a sua presença e as diretrizes a serem seguidas diante do término do período colonial. Na época, a Igreja galgava a sua hegemonia, o que lhe causava dificuldades políticas diante dos governos centrais, como a negação de direitos para sacerdotes, prisão de bispos, ensino público não confessional, casamento civil, laicização de cemitérios assim por diante. De uma maneira geral, esses conflitos revelavam disputas por poder e por influência sobre as sociedades nacionais. Ademais, a presença efetiva do clero ao longo dos territórios era quase inexpressiva. Não obstante, os sermões nas línguas nacionais também constituíam um problema a ser superado, fazendo com que os cleros nativos fossem paulatinamente substituídos pelo clero europeu, o que resolvia alguns problemas, mas originava a outros, como a dificuldade de integração e o acirramento de disputas com os poderes seculares locais (Fausto e Devoto, 2005).

No Brasil, percebeu-se desde o período colonial que as aproximações do governo central com a Igreja procuravam, em grande parte, subordinar o poder religioso ao político, a fim de usá-lo como instrumento de controle social e de ampliação do consenso popular e da unidade nacional. Aparentemente, as classes populares percebiam com maior simpatia a clássica adesão entre o trono e o altar, devido à manutenção da classe dominante colonial no regime imperial posterior, mais coadunada à ordem religiosa característica da grande propriedade escravagista brasileira (idem, 2005).

O aspecto crucial para compreender o lugar do catolicismo junto ao processo de formação da nação brasileira se encontra na sua relação com as elites nacionais,

Latitude, Vol. 9, no 2, pp. 175-195, 2015 
Identidade e diversidade religiosa no Brasil

marcadas primeiramente por uma clara divisão entre católicos, deístas e anticlericais, além da maçonaria que desempenharia papel-chave para o futuro das relações do catolicismo junto ao Estado nacional (Carvalho, 2003). Em tais relações é que o catolicismo foi se enraizando na cultura nacional. Mas os conflitos eram permanentes. Principalmente ao longo do período imperial, quando o anticlericalismo, que crescia aos olhos vistos, advinha da expansão do liberalismo, do positivismo, do darwinismo e do cientificismo em geral, emblemas da "modernidade" e da "alta cultura", especialmente daquilo que se referia ao intelectualismo francês.

À época imperial, tal crescimento do anticlericalismo e o trânsito irregular do catolicismo nas esferas de poder nacionais então independentes provocaram reações do Vaticano a partir de políticas de dogmatismo (é célebre nesta época a promulgação pelo papa Pio IX do "Sílabo dos Erros de Nossa Época" (Syllabus Errorum), em 1864, que pretendia indicar adequações, reforçar a importância e orientar aplicação de certos dogmas da Igreja para o mundo). Evidentemente, a política dogmatista gerava mais conflitos entre a Igreja e as jovens nações independentes no Ocidente, principalmente as sul-americanas, pois, a rigor, implicava na existência de um Estado internacional dentro dos recentes Estados nacionais, além de ser dogmaticamente contrária às ideias modernistas em desenvolvimento no mundo ao apostar na rigidez da ortodoxia. Algo que em certa medida distingue o Brasil de seus vizinhos de emancipação é que nossas elites nacionais latifundiárias ao tomarem o poder não quiseram tomar a governança e a burocracia do país, preferindo manter a estrutura aristocrática no império o invés do que fizeram, por exemplo, os caudilhos argentinos em 1816 ou os estancieiros uruguaios após a Guerra da Cisplatina, finda em 1828. E nesta elite aristocrática brasileira mantida no poder havia importantes setores católicos e maçons e, a bom grado da típica ética de acolhida da alteridade, alguns partilhavam de ambas as ideologias, formando sínteses de católicos-maçons ou maçons-católicos (Fausto e Devoto, 2005).

Portanto, no caso da maçonaria brasileira, muitos defendiam que não havia incompatibilidade entre ser maçom e ser católico, ideia que funcionou razoavelmente bem até a condenação absoluta da maçonaria pelo então pontífice Pio IX que iniciara a política do dogmatismo de caráter intervencionista. E foram justamente essas perseguições às elites nacionais (na figura de maçons, por 
exemplo, catalisados no notório evento da Questão Religiosa, ocorrido poucos anos antes da Proclamação da República) que definem o aspecto mais importante para o futuro jurídico secular do Estado brasileiro com o advento republicano, que previa desde a sua aurora a separação entre a Igreja e Estado, ainda que, curiosamente, o regime republicano jamais tenha eliminado o catolicismo dos ambientes de poder vigentes e vindouros.

As elites maçônicas não-católicas, que se dividiam entre republicanos, positivistas e protestantes, foram decisivas no caráter da proclamação da República no Brasil, entretanto isto não esvaziou o papel e a importância da Igreja Católica na sociedade nacional (Giumbelli, 2002). Assim, as elites governantes, aristocráticas ou não, procuraram ao longo dos tempos evitar o conflito aberto com a Igreja mediante sucessivas missões e acordos comuns, tendo em vista a utilização do catolicismo como mecanismo de controle social, mas também com certo temor diante do alto poder de mobilização local da Igreja, inclusive durante as primeiras décadas do século XX.

Além de guerras e de rebeliões populares, quando muitas vezes convinha unir forças (por exemplo, a Revolta dos Malês, 1835; a Revolta dos Muckers, 187374, a Questão Religiosa, 1872-75), registraram-se durante o século XIX diversos conflitos entre o governo e a Igreja, pois se, por um lado, a autoridade do imperador brasileiro em parte se apoiava no catolicismo como "religião do Estado", por outro, as relações entre o Império brasileiro e a Igreja católica só podiam funcionar mediante a subordinação do poder religioso ao poder temporal ou mediante a separação entre os dois. Assim, a relação constante de aproximação e de distanciamento do governo oficial com a Igreja Católica no Brasil fazia com que o Estado imperial e sua cúpula maçônica não rompessem enfaticamente com a Igreja, principalmente em função do interesse instrumental que as elites proprietárias nacionais depositavam no catolicismo como forma de manutenção da ordem social (Carvalho, 2003). O desfecho desta situação ocorreria somente com o advento da República e no texto de sua primeira Constituição, de 1891, que determinou a separação entre Igreja e Estado e a abolição jurídica do padroado e a garantia constitucional da liberdade religiosa para todos os cultos.

Ainda antes da promulgação da primeira Carta republicana, fora sancionado pelo Governo Provisório o Decreto n. 119A em sete de janeiro do ano anterior, de autoria de Rui Barbosa, que separou a Igreja Católica do Estado, extinguiu o 
Identidade e diversidade religiosa no Brasil

padroado (não por acaso um dos cernes do conflito da Questão Religiosa), proibiu os órgãos e autoridades públicas de expedir leis, regulamentos ou atos administrativos que estabelecessem religião ou a vedassem e instituiu plena liberdade de culto e de religião para os indivíduos e todas as confissões, igrejas e agremiações religiosas (Giumbelli, 2002). Estes aspectos foram mantidos na Carta Final, mas a minuta do texto ainda previa a secularização dos cemitérios, a proibição de subvenções a entidades religiosas e a criação de outras, a sujeição dos bens da Igreja à lei da "mão-morta" (estes suprimidos do texto final) e a inelegibilidade de padres seculares e religiosos para o Congresso (neste caso, no texto final ficou determinado que os seculares pudessem ser eleitos, outros religiosos não).

No Brasil, para além da hipótese maçônica, desde o advento da República, proclamada em 1889, o novo governo inspirado na forma republicana francesa e no secularismo jurídico estadunidense acompanhou o ideário existente de separação entre o Estado e a Igreja Católica, ainda que a própria França só tenha secularizado o seu Estado depois do Brasil, na primeira década do século XX. Este ideário secularizante acabou por revelar uma redefinição do campo religioso brasileiro, ocorrida ao longo do século XX. Neste século, o projeto de construção de uma "identidade nacional brasileira", que desde o esforço colonial e principalmente desde o apogeu imperial procurava se estabelecer de forma mais efetiva, mas sempre esbarrando em múltiplos desafios e com pouco alcance no vasto território nacional, recebera novo impulso no período republicano. Entretanto, somente a partir da Revolução de 1930 e da instauração da primeira Era Vargas (1930-1945), tal projeto finalmente conseguiria atingir proporções mais significativas em escala nacional. Data deste período a reelaboração ou o aparecimento de novas liturgias cíveis e políticas que procuravam estabelecer a supremacia do governo federal sobre todos os territórios e regiões do Estado, levando, consigo, uma forma própria de "cristianismo oficial" ligado à ordem e aos costumes, estando o caráter oficial agora não mais em constante disputa por legitimidade entre o governo e a cúria como esteve em tempos pré-republicanos.

Vemos que, apesar da separação constitucional entre Igreja católica e Estado, o catolicismo permaneceu sendo utilizado no Brasil como elemento de identificação religiosa das massas e de controle social pelos governos, fossem eles coloniais, imperiais, republicanos (passados ou atuais), e mesmo pelas ditaduras, de Vargas ao 
general Figueiredo. Portanto, a Igreja teve uma associação importante (ora mais conflituosa, ora mais harmônica) com os governos brasileiros desde sempre e isto foi decisivo para o enraizamento do cristianismo tanto no Estado quanto no imaginário popular e na construção de certo aspecto de nossa "identidade nacional" (Fausto e Devoto, 2005).

Contudo, no decorrer do século $X X$, verificou-se no Brasil o surgimento e/ ou crescimento e/ou maior visibilidade de outras religiões e religiosidades que iam de encontro ao ideal católico de monopólio religioso e às tentativas repressivas do Estado brasileiro que, diante da proliferação e abundância de religiosidades periféricas e da impossibilidade efetiva de regular ou combater a todas, adotou indireta e informalmente em seu processo histórico uma relativa política de tolerância generalizada, coadunando-se a tradicional representação plural da sociedade nacional que diz respeito ao campo dos costumes e da cultura popular (Segato, 1999; 2007). Esta política de tolerância, ao se notabilizar ao longo dos tempos por seu caráter encompassador, perdeu de alcance o potencial libertário, restringindo-se muito mais a uma ética de adequação e de controle da diferença sob os auspícios de dogmatismos cristãos.

Portanto, se o ethos da pluralidade penetrou e constitui nossa representação, ele não necessariamente transformou a nossa sensibilidade, marcadamente cristã. Ainda que existam outras sensibilidades, à elas a nação ofereceu historicamente pouco espaço, o que torna menos simétrica essa noção de pluralidade. Ademais, conforme sugeriu Roberto DaMatta (1997), a unidade nacional brasileira se estabeleceu mediante a interpenetração cultural de seus elementos constituintes, sendo que a cultura popular em muitas vezes substituiu o Estado em termos de afirmação da identidade nacional. Apesar de fatores constitutivos desagregadores, como o racismo na cultura e na representação dominante da nação brasileira, o conjunto dessas interpenetrações foi muitas vezes descrito como sincrético e pluralizante. Assim descritas, mas quase sempre inquestionadas.

\section{Relativizando a diversidade religiosa no Brasil: o que dizem os números}

Ainda que se verifique um particular itinerário religioso dentro da experiência religiosa do brasileiro, quer dizer, ser comum à grande parte da população uma participação em diversas formas de religiosidade ao longo de sua

Latitude, Vol. 9, no 2, pp. 175-195, 2015 
Identidade e diversidade religiosa no Brasil

vida, devido a critérios próprios de racionalidade, o projeto de homogeneização identitária de orientação cristã teve relativo sucesso no país. Possivelmente, ao responder a uma enquete oficial sobre a sua identidade religiosa, seja conveniente, senão forma de estratégia ou de resistência, declarar o pertencimento cristão, especialmente católico, conforme está representado no imaginário popular e nas instituições daquela que é tida popularmente como "a maior nação católica do mundo".

Isto repercute nos dados censitários nacionais. De acordo com eles, o Brasil até que possui relativa diversidade religiosa. Entretanto, quando observamos amiúde esses dados, percebemos a pujança que religiões de matriz cristã possuem no cenário religioso nacional.

\section{Quadro 1 - Religiões no Brasil (Censos de 1980-2010)}

\begin{tabular}{l|cccc} 
Religião & $\begin{array}{c}\text { Censo } \\
\mathbf{1 9 8 0}\end{array}$ & $\begin{array}{c}\text { Censo } \\
\mathbf{1 9 9 1}\end{array}$ & $\begin{array}{c}\text { Censo } \\
\mathbf{2 0 0 0}\end{array}$ & $\begin{array}{c}\text { Censo } \\
\mathbf{2}\end{array}$ \\
$\begin{array}{l}\text { Catolicismo } \\
\text { Romano }\end{array}$ & $89,2 \%$ & $83,3 \%$ & $73,7 \%$ & $64,6 \%$ \\
Protestantismo & $6,6 \%$ & $9 \%$ & $15,4 \%$ & $22,2 \%{ }^{2}$ \\
Espiritismo Kardecista & $0,7 \%$ & $1,1 \%$ & $1,4 \%$ & $2 \%$ \\
Afrorreligiões & $0,6 \%$ & $0,4 \%$ & $0,3 \%$ & $0,3 \%$ \\
Outras religiões & $1,3 \%$ & $1,4 \%$ & $1,9 \%$ & $2,9 \%$ \\
Sem religião & $1,6 \%$ & $4,8 \%$ & $7,3 \%$ & $8 \%$ \\
\hline Total & $100 \%$ & $100 \%$ & $100 \%$ & $100 \%$ \\
\hline
\end{tabular}

2 Protestantes assim distribuídos: 4\% são evangélicos de missão (luteranos, presbiterianos, batistas, etc), $13,3 \%$ são pentecostais e $4,8 \%$ pertencem a evangelismos não determinados. 
Fontes: Pierucci (2004) e IBGE (2014).

Atualmente, conforme os dados do censo demográfico de 2010 apresentado no quadro acima se percebe que, ao somarmos as três principais religiões de matriz cristã, chegamos ao patamar de $88,8 \%$ da população nacional (pouco mais de 169 milhões de pessoas). Considerando os $8 \%$ que se declaram sem religião, restam apenas $3,2 \%$ da população brasileira que se declara pertencente a outras religiões não necessariamente de matriz católica, isto desconsiderando, por exemplo, a umbanda ou outras religiosidades sincretizadas com o cristianismo, que poderiam diminuir ainda mais este percentual. Assim, estes módicos 3,2\% representam, conforme a catalogação do IBGE, 0,7\% (1,4 milhão) de pessoas que se declaram testemunhas de Jeová; $0,5 \%$ (um milhão) declaram-se os santos dos Últimos Dias ou mórmons; 0,3\% (588 mil) declaram-se seguidores do "animismo" afro-brasileiro como o Candomblé, o Tambor-de-mina, além da Umbanda; 1,6\% (3,1 milhões) declaram-se seguidores de outras religiões, tais como: islâmicos (300 mil), budistas (243 mil), judeus (196 mil), messiânicos (103 mil), esotéricos (74 mil), espiritualistas (62 mil) e os ayahuasqueiros (35 mil). Há ainda registros de pessoas que se declaram baha'ís e wiccanos, porém nunca foi revelado um número exato dos seguidores de tais religiões no Brasil (IBGE, 2014).

Conforme os censos nacionais, o catolicismo representava 95,2\% da população em 1940; 93,7\% em 1950, 93,1\% em 1960; 91,1\% em 1970; 89,2\% em 1980; $83,3 \%$ em 1991, até atingir os 73,8\% de 2000 e os 64,6\% de 2010 (Pierucci, 2004; IBGE, 2014). Assim, se, por um lado, observa-se historicamente o decréscimo no número de católicos, por outro se percebeu que tal refluxo católico aumentou consideravelmente os percentuais do campo protestante, especialmente das igrejas neopentecostais a partir das décadas de 1970-80.

Quanto ao crescimento protestante, os censos mostraram assim a sua evolução: 2,6\% em 1940; 3,4\% em 1950; 4\% em 1960; 5,8\% em 1970; 6,6\% em 1980; $9 \%$ em 1991; 15,4\% em 2000 e finalmente 22,2\% em 2010. Antonio Flávio Pierucci resumiu assim esta questão:

Das religiões constituintes da nossa cultura, as afrobrasileiras são as únicas não cristãs e, mesmo assim, extremamente minoritárias; tudo somado, calcula-se que

Latitude, Vol. 9, nº 2, pp. 175-195, 2015 
Identidade e diversidade religiosa no Brasil

abrangem em torno de $1 \%$ da população brasileira os que se declaram adeptos dos cultos afro. Costumo falar, de brincadeira, que o destino (religioso) do cidadão brasileiro (religioso) não é nada invejável - é converter-se de católico em protestante. [...] No Brasil de hoje, portanto, se é verdade que aumenta a oferta de alternativas religiosas, é verdade também que o que se tem de novidade são novas Igrejas cristãs ou novos movimentos católicos. Magro presente cultural, magro destino humano me parece este, de transitar do catolicismo para o protestantismo (PIERUCCI, 1999, p. 260 , grifo no original).

Ainda, segundo o autor, onde de fato residiria a alteridade na pluralidade religiosa brasileira além do campo dos discursos, das representações, do imaginário nacional assim constituído?

Cadê, por exemplo, a presença do hinduísmo, este outro prolífero e proliferante politeísmo, este Outro do Ocidente? Por causa da ditadura militar com sua censura e repressão cultural, perdemos a chance histórica de nos embeber um pouco mais do colorido e intelectualizado influxo hinduísta que invadiu os Estados Unidos da América nos anos 60-70 e deixou marcas profundas na cultura pop que desde então habita o mediascape global. Do hinduísmo herdamos, sim, em nossa atmosfera de cultura possível, informações tão interessantes como as contidas na doutrina do karma, da reencarnação dos espíritos, da evolução religiosa através da transmigração das almas de vida; mas é uma herança bem indireta, mediante o kardecismo, infiltrada portanto de cristianismo, uma vez que o próprio espiritismo kardecista nasce geneticamente atravessado pela ética do amor fraterno, referida de modo explícito ao cristianismo, aos Evangelhos, a Jesus Cristo. Ainda o cristianismo, portanto. Nosso fado? Católicos, protestantes, espíritas... a aura é 
sempre muito cristã, como se vê. Do judaísmo como religião a influência é pouca, muito pequena (a não ser indiretamente, via cristianismo, e aí então é ampla). Budismo, taoísmo, confucionismo, xintoísmo, cadê? Não passam de tímidos enclaves subculturais, em luta nada gloriosa contra o empuxo assimilacionista das segundas e terceiras gerações de imigrantes orientais, integradas já na parte branca da população. E os muçulmanos, onde foram parar? De tão desaparecidos, parece que não vieram nunca para cá. [...] Alguma teologia da libertação há de sobreviver na América Latina, pois não? Que venham pois os rastas. [...] É este, meus amigos, o tipo de votos que sinceramente faço toda vez que me dou conta de que o multiculturalismo brasileiro, decantado em prosa e verso, é ainda tão pobre, tão magro, tão limitadinho em matéria de variedade religiosa" (PIERUCCI, 1999, p. 260-61).

A diversidade religiosa é de fato muito modesta no Brasil, malgrado a tal crença deveras difundida no imaginário nacional que aposta na pluralidade, religiosa ou qual seja, como uma condição per se da nação. Neste sentido, é interessante observar que determinadas estruturas religiosas estão tão enraizadas na nação, na cultura popular, no campo político, que a pluralidade religiosa não necessariamente está atrelada a maior ou menor percepção de liberdade religiosa. No Brasil, onde se considera que nos últimos anos a liberdade religiosa atingiu patamares surpreendentes em se tratando de um país com grandes dificuldades de desenvolvimento econômico e social (Pierucci, 1996), os maiores índices de percepção de liberdade religiosa se encontram entre adeptos de religiões cristãs, não por acaso, as mais "aceitas" e estabelecidas, com maior representatividade no cenário religioso nacional.

Por exemplo, conforme pesquisa coordenada por Ari Pedro Oro (2012) na cidade de Porto Alegre sobre a percepção da liberdade religiosa ${ }^{3}$, os maiores índices

\footnotetext{
${ }^{3}$ Esta pesquisa foi realizada em Porto Alegre em 2009, utilizando uma metodologia ao mesmo tempo quantitativa e qualitativa. Na ocasião foram contatadas 384 pessoas,
}

Latitude, Vol. 9, no 2, pp. 175-195, 2015 
Identidade e diversidade religiosa no Brasil

deste reconhecimento ficaram entre os entrevistados de religiões cristãs: espiritismo kardecista (90\%), evangélicos históricos $(89,5 \%)$, pentecostais $(74 \%)$ e católicos $(73 \%)$ e os menores índices se encontram entre religiões com menor representatividade estatística no cenário nacional: afrorreligiosos (28,5\%) e novas religiões (32\%) (neopagãos, neo-xamânicos, neo-esotéricos, neo-tradicionais, ayahuasqueiros, novas religiões orientalistas ou japonesas etc) e os sem-religião (39,1\%). Por vigorar em nosso país um modelo cultural segundo o qual os vários grupos religiosos "apresentam graus distintos de inserção na sociedade nacional" (Carvalho, 1999:02) devido ao capital político e simbólico de que são detentores uns e outros, segundo Oro,

Se os afro-brasileiros, os membros das 'novas religiões' e os 'sem-religião', expressam ressalvas acerca da existência da plena liberdade religiosa em nosso país, é porque possuem alguma consciência de que não desfrutam na sociedade brasileira do mesmo status social e legitimação simbólica detido pelos outros grupos religiosos (Oro, 2012, p. 14).

Portanto, a Igreja Católica Romana soube se manter hegemônica, ao menos sob o ponto de vista do prestígio e da manutenção de sua proeminência na sensibilidade da nação. Assim, continua se pronunciando com autoridade em questões de seu interesse na vida nacional e, malgrado o aumento da visibilidade sobre a diversidade religiosa existente por aqui, ainda se constitui na religião civil brasileira, fato que repercute de maneiras diferentes, como o seu calendário que, inserido na legislação, obriga a todos a observação ddosseus feriados (Mendonça, 2003).

Assim, de certa maneira, o próprio crescimento evangélico repercute, direta ou indiretamente, tal estrutura cristã enraizada historicamente no Brasil pelo catolicismo, este cada vez mais acossado pelo avanço pentecostal, ainda que não tenha perdido a sua hegemonia como fiel depositário do cristianismo no país. Ainda

divididas segundo as porcentagens de filiações religiosas que vigoram na capital gaúcha, segundo o Censo 2000, e a elas solicitou-se que se posicionassem diante do enunciado: "no Brasil existe total liberdade religiosa?" (Oro, 2012). 
assim, é importante destacar que os dados censitários, por si só, não levam em consideração as diferentes maneiras pelas quais os indivíduos vivenciam experiências plurais no Brasil em termos de trânsitos religiosos. Contudo, indicam a prevalência do cristianismo em suas auto-atribuições religiosas, o que não deixa de ser significativo enquanto aspecto identitário da nação.

\section{A ascensão pentecostal, a prevalência cristã}

Nas últimas décadas, a prevalência cristã e a atualização de sua ortodoxia mais conservadora por parte de muitos grupos evangélicos nacionais também atualizaram os desafios para as políticas de identidade e de laicização do Estado brasileiro (Tadvald, 2015).

Estabelecido o campo católico, o cristianismo recebeu novo impulso a partir do crescimento evangélico verificado após a reabertura política, em 1985, muito em função do advento do neopentecostalismo, que tem como marco histórico o surgimento, no Rio de Janeiro, da Igreja Universal do Reino de Deus (IURD), em 1977. Além do neopentecostalismo de massas e dos evangélicos históricos, de pertencimento mais atrelado a comunidades étnicas ou regionais, ainda se observa nas últimas décadas o crescimento de um novo tipo de evangélico, mais independente e com menor fidelidade denominacional, fenômeno que inclusive repercutiu na diminuição no número de fiéis de igrejas neopentecostais estabelecidas há mais tempo, mas que fez aumentar o percentual dos evangélicos em geral no país (Mariano, 2005).

Apesar da pujança e da visibilidade que gozam grandes igrejas neopentecostais, os números atuais do protestantismo nacional ainda mostram o crescimento substancial de fiéis que se dizem apenas evangélicos, sem vinculação direta a nenhuma igreja. E vale considerar que nem todas as igrejas estão previstas no livro-código do Censo, de sorte que podemos especular que muitas atribuições caem na variável "outras igrejas". Por outro lado, é de se considerar que de fato outros tantos evangélicos circulam entre diferentes denominações, sem que se tornem adeptas de alguma em especial, cumprindo, ao seu modo, com a dinâmica do itinerário religioso tipicamente nacional já referido. Estes aspectos podem contribuir para compreender o crescimento substancial de integrantes de religiões "evangélicas não determinadas", que saltou de 1,7 milhões de pessoas, em 2000, para 9,2 milhões, em 2010, percentuais superiores aos dos espíritas kardecistas (2\%)

Latitude, Vol. 9, nº 2, pp. 175-195, 2015 
Identidade e diversidade religiosa no Brasil

e dos adeptos de outras religiões (2,7\%) (IBGE, 2014). Outro aspecto que pode estar relacionado com o crescimento de evangélicos "sem igrejas" é o fenômeno da música gospel, que atrai milhões de fãs, independente de suas filiações denominacionais, quando existe alguma.

Temos assim a profusão de pequenas igrejas pentecostais que atualmente disputam fiéis com as grandes denominações. Essas novas igrejas estão dividas em dois tipos: de um lado, as menores, mais "festivas", e que atraem mais jovens; de outro, aquelas inspiradas no modelo neopentecostal, que trabalham tenazmente com princípios da Teologia da Prosperidade, centralizadas na figura de uma liderança carismática e com forte inserção nos meios de comunicação, abertura em profusão de grandes e pequenos templos, assim por diante.

Socialmente, o pentecostalismo brasileiro agrega camadas mais empobrecidas da população, ainda que existam denominações mais voltadas para as camadas médias e altas. Mas é fundamentalmente o sucesso da Teologia da Prosperidade, promovido especialmente pelo neopentecostalismo, que contribui em boa medida para explicar o exponencial crescimento evangélico, posto que, de modo questionável, responde melhor aos desafios modernos de inclusão social e ascensão material dentro da nova lógica do capitalismo global, nem que esta ascensão se restrinja ao campo simbólico e não material. O pentecostalismo atual também possui a capacidade de agregar muitas pessoas em busca de sistemas de cura espiritual e da resolução de problemas do cotidiano, de ordem material, familiar, emocional, psicológica entre outros (Mariano, 2005).

Há de se levar também em consideração a ascensão evangélica no campo político. Desde a reabertura, os evangélicos tem se inserido de forma contundente nesta arena sob a principal justificativa de lá combater as forças demoníacas que assolam o espaço público. Com o tempo, diante da defesa de temas políticos comuns, preferencialmente relacionados aos campos da moral e dos costumes, os deputados federais evangélicos formaram a Frente Parlamentar Evangélica (FPE), popularmente chamada de "bancada evangélica", que tem recebido, e não de hoje, considerável atenção da sociedade nacional, muito em função de seu exponencial crescimento. Não há como avançar a contento no tema neste momento, mas o cenário político brasileiro e sua "invasão de religiosos" é fato digno de nota por se tratar de um privilegiado panóptico da tensão entre identidades nacionais contrastantes, representantes do ethos plural da nação, desta pluralidade em que se 
tem destacado mais ultimamente a sua face mais conservadora. Tal fenômeno tratase, ao cabo, da manutenção e da atualização moderna do dogmatismo cristão nas esferas legais de poder.

Todos estes expedientes e instituições são portadores de códigos e de referenciais cristãos particulares que, ao seu modo ressignificados, somarão ao repositório cultural formador de identidades religiosas brasileiras e ao seu caráter tipicamente encompassador, adequador e controlador da diferença.

\section{5. À guisa de conclusão: em busca do tempo plural}

O que reúne e atrai as pessoas não é a semelhança ou identidade de opiniões, senão a identidade de espírito, a mesma espiritualidade ou maneira de ser e entender a vida. Marcel Proust

A fim de encaminhar uma reflexão final, compartilho uma experiência pessoal que entendo refletir diversos argumentos que tenho abordado durante este trabalho. Anos atrás, eu estava na calçada de casa conversando com meu vizinho quando fui abordado por uma jovem que desejava saber onde ficava a "Casa do Pai Fulano", um conhecido pai-de-santo da região que possui um tradicional terreiro de batuque, esta que é a modalidade afrorreligiosa tipicamente gaúcha. Depois de agradecer pela informação, para minha surpresa e de forma absolutamente espontânea, a jovem me confidenciou que procuraria o terreiro para fazer um "trabalho de proteção" para o seu namorado, que iria assaltar um banco no dia seguinte, e seguiu o seu caminho para eu nunca mais saber dela ou do desfecho daquela história.

Tempos depois eu estudava a matriz filosófica e teosófica das afrorreligiões brasileiras para verificar que, enquanto matriz idealizada, as noções de bem e de mal tipicamente africanas são relativas se tivermos como referência a lógica cristã, quer dizer, em um terreiro, em uma casa de santo, fazer algo que é "bom" para um sujeito pode não ser necessariamente "bom" para outro, mas isto não desqualifica o valor e a importância da primeira ação pela perspectiva do primeiro sujeito, por isso uma entidade do panteão afrorreligioso pode fazer algo condenável por outra 
Identidade e diversidade religiosa no Brasil

pessoa, no sentido de estar ajudando ao seu demandante. Quer dizer, a lógica de bem e de mal são construídas de forma menos ortodoxa e preestabelecida do que a cristã. A lógica afrorreligiosa original ou típica é mais relativa, portanto. E note-se que, para efeito reflexivo, acaba se tornando imperativo para o nosso entendimento (de base cristã) a análise a partir de categorias cristãs, como bem e mal. Na idealizada matriz africana "genuína", há, portanto, uma inexorável intraduzibilidade cultural e simbólica desta matriz a partir de termos cristãos. No Brasil, pela "lógica da acolhida" da alteridade comum à construção de pessoa, também não há constrangimento religioso em recorrer a práticas ou intenções diferentes da lógica pública dominante, contanto que respeitados certos limites e implicações preestabelecidas e compartilhadas mutuamente devido a processos comuns de socialização ou a contingências culturais regionais.

Diante dessas questões, resolvi à época questionar alguns pais e mãe-desanto de minhas relações sobre a natureza de alguns de seus "trabalhos" e "feitiços", realizados sob sua gerência. Para tanto, contei-lhes aquela história sobre o assalto ao banco e todos os afrorreligiosos que consultei, sem exceção, disseram-me que jamais fariam algo semelhante para ajudar aquela jovem ou ao seu namorado, porque "estava errado", simples assim. Também me disseram que não fazem "trabalhos" (feitiços) para prejudicar alguém, como "roubar" o emprego ou a "namorada" de outra pessoa, mesmo que a ação favoreça seus demandantes, em muitos casos seus próprios filhos-de-santo, estes que, a propósito, já são "educados" na religião e pela sociedade desde crianças dentro desta mesma perspectiva, digamos assim, "cristianizada" de bem e de mal, de certo e de errado.

Assim, o exemplo revela que, diante dos questionamentos sobre a ideia de bem e de mal, certo e errado, o maniqueísmo intrínseco à lógica cristã que incide sobre tais representações repercute na experiência religiosa de comunidades afroorientadas que se autodeclaram não possuir o sincretismo católico, como o batuque gaúcho, no caso destes interlocutores a pouco referendados. Assim, deixando de lado os sincretismos já reconhecidos, seria exagero perceber formas múltiplas de interpenetrações do cristianismo em outras religiosidades que encontramos no país, como modalidades de xamanismo ou religiosidades orientais? Temos aí uma interessante questão para pesquisas vindouras.

Mas ao menos em se tratando de Brasil, não estamos diante de qualquer contradição quando percebemos tais interpenetrações, pois soubemos 
introduzir o aspecto da contradição em nosso repositório identitário. Esta é a forma que desenvolvemos para lidar com ela, com os conflitos entre o plural e o conservadorismo homogeneizante. Por aqui, apesar de largamente vivenciado, o conflito não é conveniente para a experiência nacional. As interpenetrações identitárias também se justificam, conforme Rita Segato (2007), porque no Brasil o indivíduo conseguiu preservar para si a possibilidade da dupla afiliação de seu trânsito entre distintos lugares de identidade, construindo-se como uma espécie de sujeito em trânsito, de sujeito plural. A ruptura de laços de obrigação pré-modernos com a comunidade e com a família não resultou necessariamente numa maior liberdade da opção religiosa por parte dos indivíduos, mas antes fragilizou o seu alinhamento em redes de alianças e comunidades de sentido preestabelecidas e determinadas. Portanto, no Brasil, respaldado pela semântica nacional da pluralidade, ainda que ela não seja necessariamente inclusiva, é possível uma maior autonomia de atribuição religiosa, mas preferencialmente cristã e a partir da constituição de interpretações e de sentidos múltiplos sobre a religiosidade pessoal.

Marcar-se socialmente, então, consiste em uma importante função de determinada identidade, qual ela seja, algo que deve informar aos demais certos alinhamentos éticos, morais, políticos, religiosos, sexuais ou de gênero, dentre outros, aos quais pertencem certos indivíduos. Assim, a identidade brasileira, como constructo simbólico e observada a partir da nossa sociedade e de suas instituições, tem se reanimado com o caráter plural e libertário oferecido a ela mediante lutas e demandas sociais promovidas por diversos grupos em prol de políticas de reconhecimento de suas identidades e direitos. Contudo, fundamentalmente, esta mesma sociedade ainda não conseguiu perder de vista o seu referencial conservador, que assim lhe estrutura graças a complexos e históricos processos políticos e sociais. Tal caráter nacional conservador aparece, em grande medida, nas identidades religiosas que temos por aqui, marcadas sistematicamente pelo cristianismo.

\section{Referências}

CAPONE, Stefania. La quête de l'Afrique dans le Candomblé: pouvoir et tradition au Brasil. Paris: Karthala, 1999. 
Identidade e diversidade religiosa no Brasil

CARVALHO, José Jorge de. Um espaço público encantado: pluralidade religiosa e modernidade no Brasil. Série Antropologia, Brasília, v. 249, 1999.

CARVAlHO, José Murilo de. A Construção da Ordem - Teatro de Sombras. São Paulo: Civilização Brasileira, 2003.

COSTA, E. V. Da senzala à colônia. São Paulo: Editora da UNESP, 1998.

DAMATTA, Roberto. Carnavais, malandros e heróis: para uma sociologia do dilema brasileiro. Rio de Janeiro: Rocco, 1997.

FAUSTO, Boris; DEVOTO, Fernando J. Brasil e Argentina: um ensaio de história comparada. São Paulo: Editora 34, 2005.

GIUMBELLI, Emerson. O fim da religião: dilemas da liberdade religiosa no Brasil e na França. São Paulo: Attar Editorial, 2002.

IBGE. Censo de 2010. www.ibge.gov.br. Consultado em 13 de Dez. 2014.

MARIANO, Ricardo. Neopentecostais: sociologia do novo pentecostalismo no Brasil. São Paulo: Loyola, 2005.

MENDONÇA, Antônio Gouvêa. República e pluralidade religiosa no Brasil. Revista USP, São Paulo, n.59, p. 144-163, set/nov 2003.

ORO, Ari Pedro. Religião e política no Brasil. In: ORO, Ari P. (Org.). Religião e política no Cone Sul: Argentina, Brasil e Uruguai. São Paulo: CNPq/PRONEX, Attar Editorial, 2006, p. 75-156.

ORO, Ari Pedro. Liberdade religiosa no Brasil: as percepções dos atores sociais. In: ORO, A. P. et ailli (Orgs.). A religião no espaço público: atores e objetos. São Paulo: Terceiro Nome, 2012, p. 181-193.

PIERUCCI, Antonio Flavio. Liberdade de cultos na sociedade de serviços. In: PIERUCCI, A. C; PRANDI, R. (Orgs). A realidade social das religiões no Brasil. São Paulo: Hucitec, 1996, p. 275-293.

PIERUCCI, Antonio Flavio. Interesses religiosos dos sociólogos da religião. In: ORO, Ari P. STEIL, Carlos Alberto (Orgs). Globalização e religião. Petrópolis: Editora Vozes, 1999, p. 249-262.

PIERUCCI, Antonio Flavio. Bye bye, Brasil: o declínio das religiões tradicionais no Censo 2000. Estudos Avançados, vol.18, n. 52, São Paulo, Set./Dec. 2004.

SANCHIS, Pierre. O campo religioso contemporâneo no Brasil. In: ORO, Ari P; STEIL, Carlos Alberto (Orgs.) Globalização e religião. Petrópolis: Editora Vozes, 1999, p. 103115. 
SEGATO, Rita Laura. Formações de diversidade: nação e opções religiosas no contexto da globalização. In: ORO, Ari P; STEIL, Carlos Alberto (Orgs.) Globalização e religião. Petrópolis: Editora Vozes, 1999, p. 219-248.

SEGATO, Rita Laura. La nación y sus otros: raza, etnicidad y diversidad religiosa en tiempos de Políticas de la Identidad. Buenos Aires: Prometeo Libros, 2007.

TADVALD, Marcelo. Corpo e possessão na teodicéia racionalista do espiritismo kardecista. Ciencias Sociales y Religión/ Ciências Sociais e Religião, Porto Alegre, ano 9, n. 9, p. 117-139, setembro de 2007.

TADVALD, Marcelo. Veredas do sagrado: Brasil e Argentina no contexto da transnacionalização religiosa. Porto Alegre: Editora Cirkula, 2015.

VELHO, Gilberto. Indivíduo e religião na cultura brasileira. In: VELHO, G. Projeto e metamorfose: antropologia das sociedades complexas. Rio de Janeiro: Jorge Zahar, 1994. 